\title{
Formation of pale foam glass from colored glass cullet
}

\author{
Tomoko AKAI ${ }^{1}$, Kohei FUKUMI ${ }^{1, \dagger}$ and Masaru YAMASHITA ${ }^{1}$ \\ ${ }^{1}$ Inorganic Functional Material Research Institute, National Institute of Advanced Industrial Science and Technology, \\ 1-8-31 Midorigaoka, Ikeda, Osaka 563-8577, Japan
}

The decolorization of foam glasses made from green and amber glass cullets was attempted. It was found that the addition of silicon carbide $(\mathrm{SiC})$ and zinc oxide $(\mathrm{ZnO})$ as decolorizing agents was effective for the decolorization of both the foam glasses made from green and amber glasses. Therefore, the addition of $\mathrm{SiC}$ and $\mathrm{ZnO}$ was suitable for the decolorization of foam glass made from the mixture of green, amber and colorless glasses. (C2020 The Ceramic Society of Japan. All rights reserved.

Key-words : Foam glass, Glass recycle, Decolorization, Zinc oxide, Silicon carbide

[Received October 18, 2019; Accepted December 24, 2019]

\section{Introduction}

Used glass bottles are recycled into products such as bottles, short glass fibers, and aggregates for subgrade and base. More than $90 \%$ of colorless and amber (brown) glass bottles are recycled as raw materials of glass bottles. Only $40 \%$ of glass containers in other colors are, however, recycled into glass bottles in Japan. ${ }^{1)}$ Consequently, the cullet price of green and mixed glasses (the mixture of amber, green and colorless glasses) is lower than that of colorless and amber glass. Therefore, the cullet of green and mixed glasses is a cost-effective material and is suitable for use of civil engineering materials.

Foam glass is one of the usage of the mixed cullet. Many studies have been carried out on the foaming process, the reaction mechanism between glass and foaming agent and the effect of preparation conditions, such as foaming temperature, foaming time, particle size and type of foaming agent, on the properties of foam glasses. ${ }^{2-7)}$ Foam glasses are used as a lightweight aggregate, an aggregate for heat insulation blocks, a drain-improving material for agriculture, a crime-preventive gravel that produces sounds due to stamping, etc. ${ }^{8)-14)}$ Consumers prefer using white foam glass on a ground face, such as crime-preventive gravel. White crime-preventive gravel is currently produced from colorless glass cullet. We aim to study the use of mixed colored glass cullet as a costeffective material for producing white foam glass.

It is known that the coloration of amber glass is caused by the charge transfer electronic transition in $\left[\mathrm{Fe}^{3+} \mathrm{O}^{2-}{ }_{3} \mathrm{~S}^{2-}\right]^{5-}$ chromophore. ${ }^{15), 16)}$ Decolorization of amber glass has been realized by adding zinc oxide $(\mathrm{ZnO})$ to amber glass cullet during the remelting of glass, ${ }^{16), 17)}$ since sulfide ions and oxide ions are exchanged

\footnotetext{
Corresponding author: K. Fukumi; E-mail: fukumi-kohei@ aist.go.jp
}

between $\left[\mathrm{Fe}^{3+} \mathrm{O}^{2-}{ }_{3} \mathrm{~S}^{2-}\right]^{5-}$ chromophore and $\mathrm{ZnO}$ during remelting and the resultant $\mathrm{Fe}^{3+}$ ions coordinated with only oxide ions and $\mathrm{ZnS}$ exhibit weak or no absorption in the visible ray region. ${ }^{16)}$ Foam glass is, however, produced at lower temperatures than the melting temperature (liquidus temperature), for the retention of bubbles in glass. Therefore, it is important to study the decolorization of amber glass at temperatures lower than the melting temperature at first. The coloration of green glass is caused by the $\mathrm{d}-\mathrm{d}$ transition in $\mathrm{Cr}^{3+}$ ions. ${ }^{18)}$ The decolorization of green glass has not been studied so far, since divalent, trivalent, tetravalent and hexavalent $\mathrm{Cr}$ ions, all exhibit optical absorption in visible ray region. ${ }^{18), 19)}$ Therefore, it is also important to develop the decolorization method of green glass. One possible method of decolorization is the incorporation of light scatterers such as fine bubbles in glasses, which would lighten colors, although this method is applicable only to opaque glasses such as foam glass. In the present study, we have attempted to produce white foam glass from the cullets of amber glass, green glass and the mixture of colorless, amber and green glasses.

\section{Experimental procedures}

Waste glass cullets of colorless, amber and green glasses were obtained from waste traders. The viscosity of the colorless, amber and green glasses was measured with an indentation, parallel-plate, and parallel-plate-rotation-type viscometer (PRVM-1100, OPT Corp.). The equal weight mixture of the colorless, amber and green glasses was prepared as a "mixed glass". The glass cullets of amber, green and mixed glasses were crushed to a particle size less than $100 \mu \mathrm{m}$. Three grams of crushed cullet was mixed with 0.5 mass $\%$ of $\mathrm{CaCO}_{3}$ powder (reagent grade, Wako) as a foaming agent, and 0 to 2 mass \% of $\mathrm{ZnO}$ (reagent grade, Kishida) and 0 to 0.4 mass \% silicon carbide (SiC) (\#8000, Green Carbo, Fujimi) as decoloring agents. The mixture 
was put in an alumina crucible, heated up to $850^{\circ} \mathrm{C}$ at a heating rate of $9.2^{\circ} \mathrm{C} / \mathrm{min}$, kept at $850^{\circ} \mathrm{C}$ for $30 \mathrm{~min}$ and allowed to cool, in an ambient atmosphere within an electric furnace, to obtain foam glasses.

The foam glasses so obtained were observed with a digital microscope (VHX-500, Keyence). The $L^{*} a^{*} b^{*}$ color coordinates were measured at bottom surfaces of foam glasses with a colorimeter (CM-600d spectro-photometer, Konica Minolta), and were converted to $L^{*} C^{*} h$ coordinates, since the higher brightness $\left(L^{*}\right)$ and lower metric chroma $\left(C^{*}\right)$ are desirable color change. The measurement errors of $L^{*}, C^{*}$ and $h$ were within $0.7,0.3$ and 0.5 , respectively. X-ray diffraction measurement was carried out for the foam glasses made from the green glass. The density and porosity of a foam glass made from green glass cullet was measured by the Archimedes method using water as the immersion liquid.

Electron-spin resonance (ESR) spectra of glass samples without a foaming agent were measured with a conventional X-band ESR spectrometer (300E ESR spectrometer, Bruker). The appropriate mixture of $\mathrm{SiO}_{2}$ (Cerac, 99.99\%), $\mathrm{Na}_{2} \mathrm{CO}_{3}$ (Asahi Glass, 99.97\%), $\mathrm{CaCO}_{3}$ (Cerac, 99.999\%) and $\mathrm{Al}_{2} \mathrm{O}_{3}$ (Cerac, 99.99\%) was melted in a Pt crucible to form $16 \mathrm{Na}_{2} \mathrm{O}-10 \mathrm{CaO}-1 \mathrm{Al}_{2} \mathrm{O}_{3}-73 \mathrm{SiO}_{2}$ glass. The glass was crushed into powder, mixed with 2 mass $\% \mathrm{ZnO}$ and 0.2 mass $\% \mathrm{SiC}$, and heated at $850^{\circ} \mathrm{C}$ for $30 \mathrm{~min}$. The glass sample so obtained was cut to dimensions of $2 \times 2 \times 25$ $\mathrm{mm}$ for ESR measurement. The measurement was carried out at a 5-mW power, 0.5-mT modulation amplitude, and $100-\mathrm{kHz}$ frequency, at room temperature. The g-value was corrected by measuring a strong pitch.

\section{Results and discussion}

Figure 1 shows the viscosity-temperature curves of colorless, amber and green glasses. These curves overlapped each other, showing that these glasses can be heattreated at the same temperature for the production of form glass. Since it is known that the viscosity range for the formation of foam glass is $10^{6}$ to $10^{4} \mathrm{dPa} \mathrm{s}^{4)}$ and that $\mathrm{CaCO}_{3}$ is decomposed to evolve gaseous $\mathrm{CO}_{2}$ at temperatures ranging from 600 to $850{ }^{\circ} \mathrm{C},{ }^{20}$ ) the heat treatment was carried out at $850^{\circ} \mathrm{C}$ in the present study. All the foam glasses had bubbles of diameters less than $1 \mathrm{~mm}$, as shown in Figs. 2 and 3. The true density, apparent density, bulk

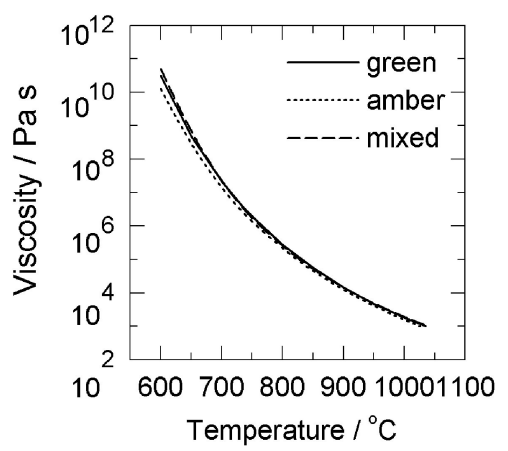

Fig. 1. Viscosity-temperature curves of green, amber and colorless glasses. density, total porosity, open porosity and closed porosity were $2.55 \pm 0.01,0.59 \pm 0.01$ and $0.51 \pm 0.01 \mathrm{~g} \mathrm{~cm}^{-3}$, $79 \pm 1,13 \pm 1$ and $66 \pm 1 \%$, respectively, in the foam glass made from green glass cullet with 2 and 0.2 mass $\%$ $\mathrm{SiC}$.

\subsection{Green glass cullet}

$L^{*} C^{*} h$ values of foam glasses made from green glass cullet are depicted in Fig. 4. The sole addition of $\mathrm{ZnO}$ as a decoloring agent slightly increased $L^{*}$ (brightness), although $C^{*}$ (chroma) and $h$ (hue angle) were scarcely changed. Since $\mathrm{ZnO}$ has refractive index higher than the glass and $\mathrm{ZnO}$ is transparent in the visible ray region, it is deduced that $\mathrm{ZnO}$ acts as simple light scatterers in the foam glass, which increased $L^{*}$. On the other hand, unexpectedly, the sole addition of $\mathrm{SiC}$ caused the change in $h$ from 128 to $90^{\circ}$, the decrease in $L^{*}$ and the increase in $C^{*}$, indicating that the color changed from green to yellow and became deeper by the addition of $\mathrm{SiC}$. The addition of both $\mathrm{SiC}$ and $\mathrm{ZnO}$ caused the change in $\mathrm{h}$ from 128 to $111^{\circ}$, the increase in $L^{*}$ and the decrease in $C^{*}$, indicating that the color changed from green to lime green and became paler. The foam glass in which 2 mass $\% \mathrm{ZnO}$ and 0.1 mass \% SiC were contained looks pale lime green color, although the foam glass with no additives looks green color, as shown in Fig. 2.

Figure 5 shows the X-ray diffraction patterns of the green foam glasses. It can be seen that partial crystallization occurred and that the diffraction patterns were almost independent of the addition of $\mathrm{SiC}$ and $\mathrm{ZnO}$, showing that the color change by the addition of $\mathrm{SiC}$ was not due to the partial crystallization. Figure 3 shows the optical microscopic image of the glasses. Much more fine bubbles with a size less than about $10 \mu \mathrm{m}$ were formed in the glasses in which $\mathrm{SiC}$ was added than in the glasses in which $\mathrm{SiC}$ was not added. Therefore, it is deduced that the addition of SiC causes many fine bubbles through the oxidation reaction, which acts as light scatterers. Although $\mathrm{SiC}$ is often used as a foaming agent which forms large bubbles in glasses

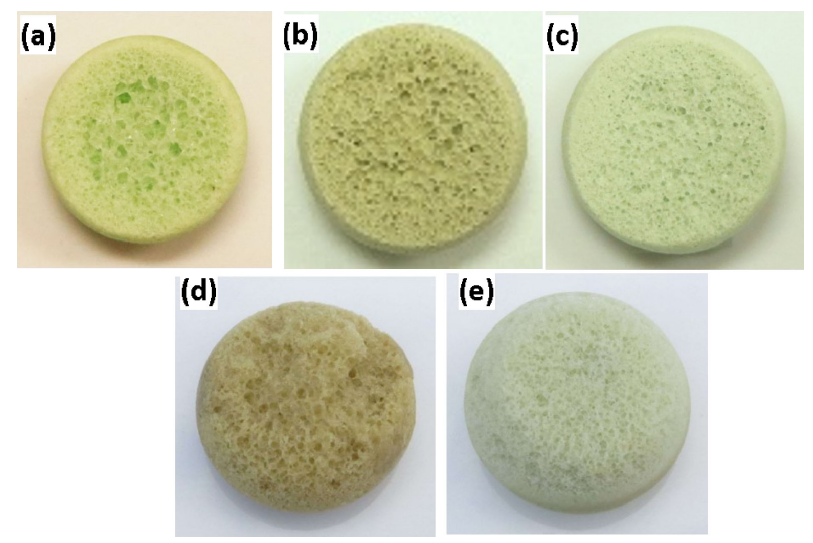

Fig. 2. Bottom surfaces of foam glasses made from (a) green glass cullet with no decolorizing agents, (b) green glass cullet with 0.1 mass $\% \mathrm{SiC}$ (c) green glass cullet with 2 mass $\% \mathrm{ZnO}$ and 0.1 mass $\% \mathrm{SiC}$, (d) amber glass cullet with no decolorizing agents (e) amber glass cullet with 2 mass $\% \mathrm{ZnO}$. 

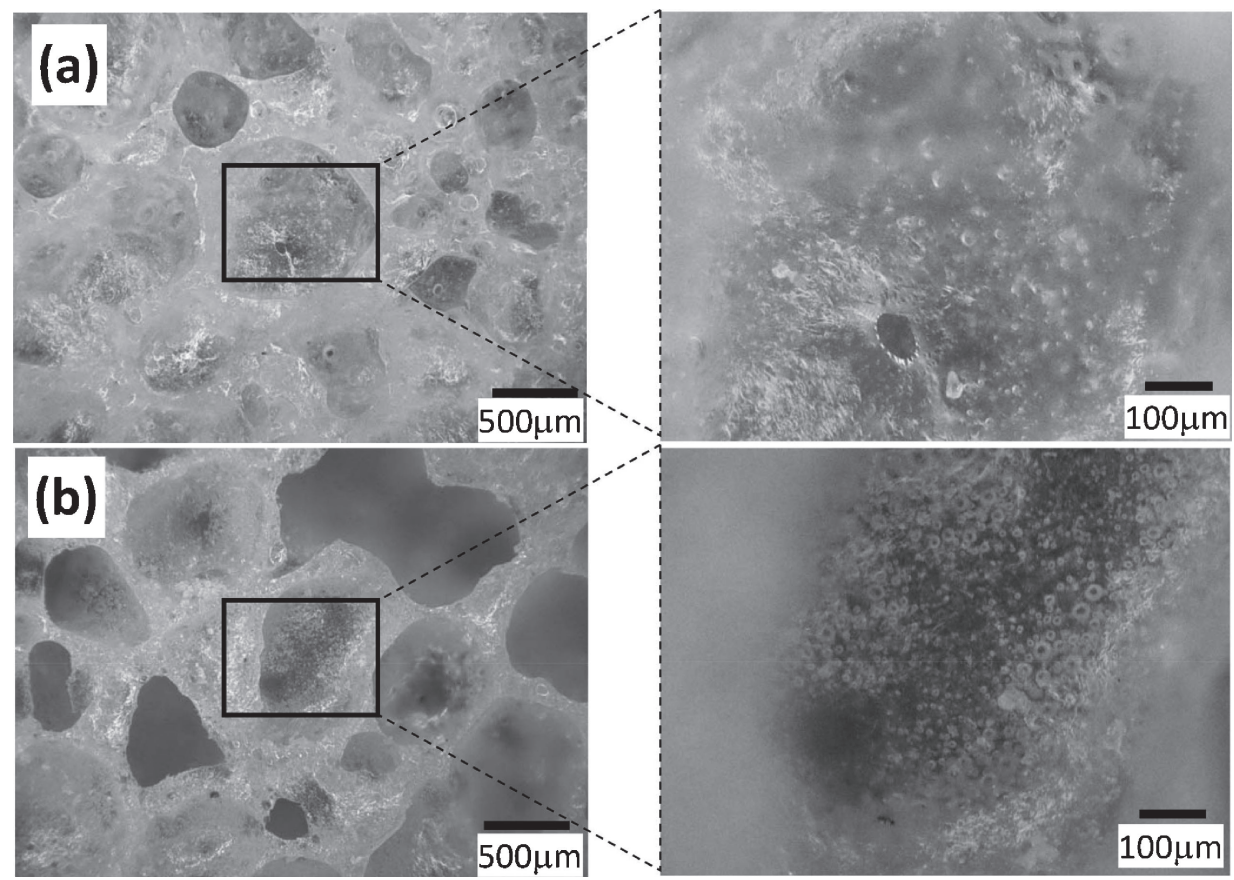

Fig. 3. Optical microscopic images of foam glasses containing (a) 2 mass $\% \mathrm{ZnO}$ and (b) 2 mass $\% \mathrm{ZnO}$ and 0.2 mass \% SiC, as decolorizing agents.

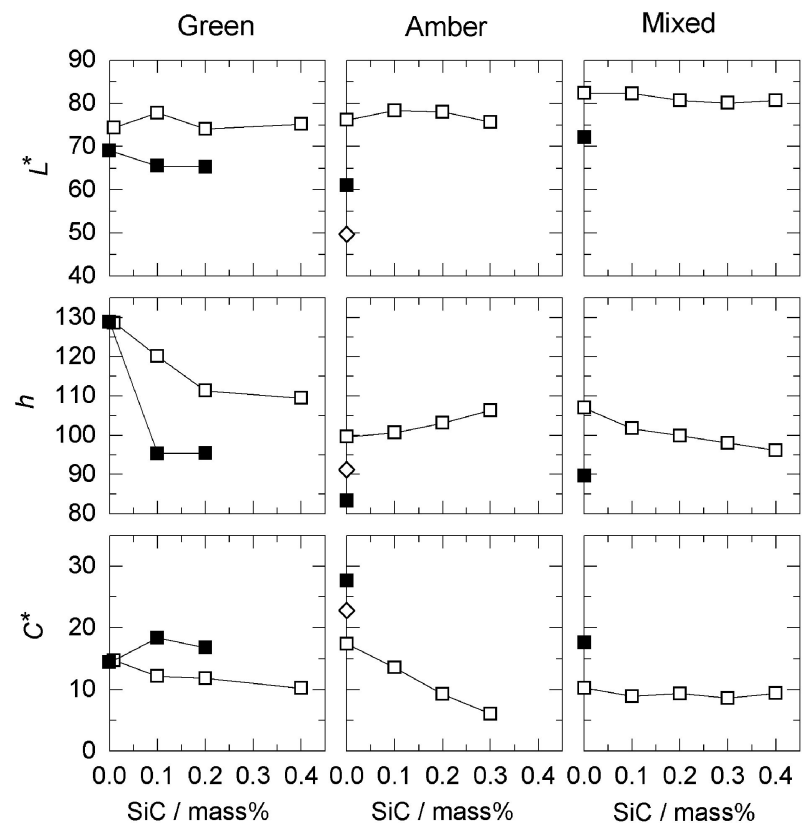

Fig. 4. $L^{*} C^{*} h$ coordinates of foam glasses made from green glass cullet, amber glass cullet and mixed glass cullet. Open and closed squares represent foam glasses with and without 2 mass \% $\mathrm{ZnO}$, respectively. A diamond represents a glass containing 2 mass $\% \mathrm{ZnO}$ and no forming agent $\left(\mathrm{CaCO}_{3}\right)$.

after heating at temperatures higher than $1000^{\circ} \mathrm{C}^{5)}$ fine bubbles were formed by the addition of $\mathrm{SiC}$ owing to the lower heating temperature in the present study. It is unlikely, however, that fine bubbles cause the color change. It is expected, rather, that fine bubbles increase only $L^{*}$, similar to $\mathrm{ZnO}$, in contrast to the experimental results. This discrepancy was discussed in the following section.

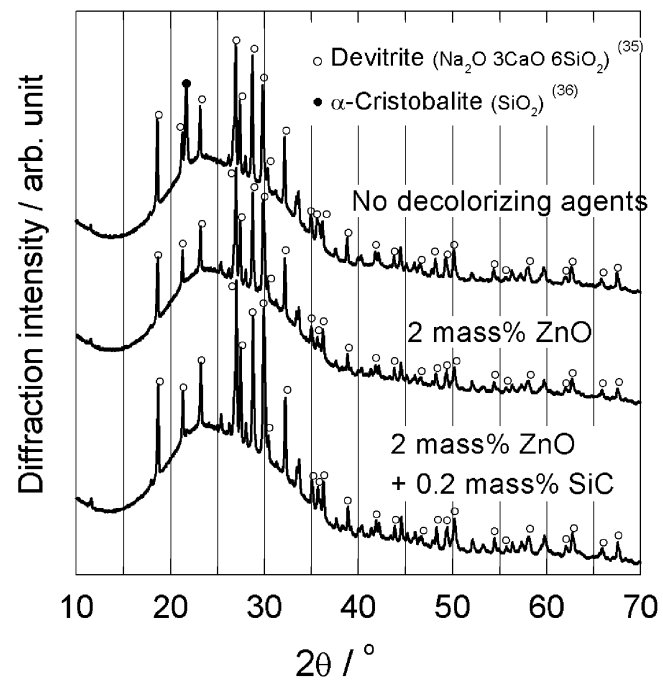

Fig. 5. X-ray diffraction profiles of foam glass made from green glass cullet.

Extensive studies have been performed on the oxidation of $\mathrm{SiC}$ and the reaction between $\mathrm{SiC}$ and glasses. ${ }^{21-24)}$ It has been shown that $\mathrm{C}, \mathrm{CO}$ or $\mathrm{CO}_{2}$ is formed as well as $\mathrm{SiO}$ and $\mathrm{SiO}_{2}$ at the interface between $\mathrm{SiC}$ and glasses. ${ }^{5), 21)}$ According to the result of ESR measurement shown in Fig. 6, an ESR signal was observed at $g \sim 2.0025$ in the glass in which $\mathrm{SiC}$ was added, although such a signal was not observed in the glass in which $\mathrm{SiC}$ was not added. Since the $g$ value of this signal was close to that of dangling bonds of carbon atoms in amorphous carbon observed in $\mathrm{SiO}_{2} / \mathrm{SiC}$ interface, ${ }^{25), 26)}$ the presence a signal at $g \sim 2.0025$ shows the formation of carbon layer in the present glass. From the view point of absorption coef- 


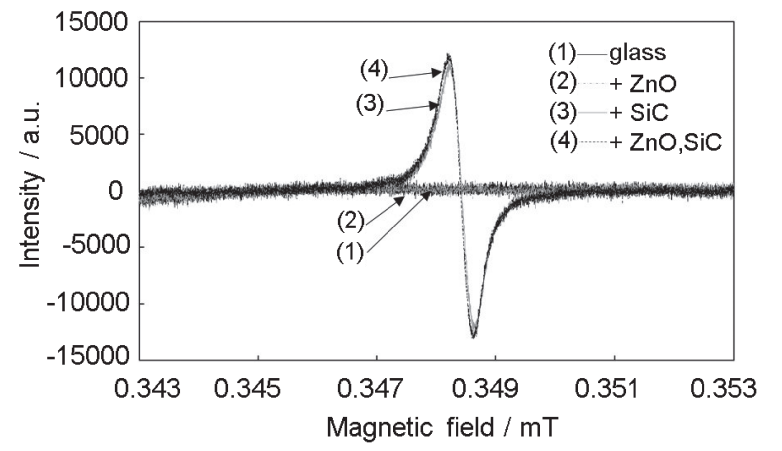

Fig. 6. ESR spectra of $16 \mathrm{Na}_{2} \mathrm{O}-10 \mathrm{CaO}-1 \mathrm{Al}_{2} \mathrm{O}_{3}-73 \mathrm{SiO}_{2}$ glasses with and without $\mathrm{ZnO}$ and $\mathrm{SiC}$.

ficient (the absorption coefficients of amorphous carbon, green $\mathrm{SiC}$ and $\mathrm{SiO}$ were $1.9 \times 10^{5}, 96$ and $2.2 \times 10^{3} \mathrm{~cm}^{-1}$ at a wavelength of $450 \mathrm{~nm}$ and $1.1 \times 10^{5}, 94$, and $1.5 \times$ $10^{2} \mathrm{~cm}^{-1}$, at a wavelength of $650 \mathrm{~nm}$, respectively), ${ }^{27)-29)}$ carbon has the highest coefficient. Since the densities of glass and amorphous carbon are 2.55 and $2.1 \mathrm{~g} \mathrm{~cm}^{-3}$, respectively, it is expected that the transmittance for 0.1 $\mathrm{mm}$ thickness at $650 \mathrm{~nm}$ is 5 percent higher than that at $450 \mathrm{~nm}$, assuming that only $10 \%$ of $\mathrm{SiC}$ is converted to amorphous carbon. Therefore, carbon probably acted as light absorbers, which changed color and decreased $L^{*}$ in the foam glass.

The addition of $\mathrm{ZnO}$ suppressed the effect of $\mathrm{SiC}$ on the values of $L^{*}$ and $\mathrm{h}$ in the foam glass in which both $\mathrm{SiC}$ and $\mathrm{ZnO}$ were added. This suppression is due to the decrease of the fraction of light which arrives at carbon. On the other hand, it is unclear why the co-addition of $\mathrm{SiC}$ and $\mathrm{ZnO}$ reduced $C^{*}$.

\subsection{Amber glass cullet}

$L^{*} C^{*} h$ values of foam glasses made from amber glass cullet are depicted in Fig. 4. The sole addition of $\mathrm{ZnO}$ increased $L^{*}$ and decreased $C^{*}$, indicating the decolorization of the glass. In addition, $h$ changed from 83 to $100^{\circ}$, that is, the color changed from amber to green. These findings indicate that the reaction between $\left[\mathrm{Fe}^{3+} \mathrm{O}^{2-}{ }_{3} \mathrm{~S}^{2-}\right]^{5-}$ chromophore and $\mathrm{ZnO}$ occurred at a temperature of $850^{\circ} \mathrm{C}$ to form $\left[\mathrm{Fe}^{3+} \mathrm{O}^{2-}{ }_{4}\right]^{5-}$ and $\mathrm{ZnS}$. The green color was due to the $\mathrm{Fe}^{2+}$ ions which coexisted with $\mathrm{Fe}^{3+}$ ions in the glass. ${ }^{16), 30)}$ Since it is known that the chromophore starts to decompose at a temperature of $550^{\circ} \mathrm{C}$ and most sulfur exists as free $\mathrm{S}^{2-}$ at temperatures higher than $700{ }^{\circ} \mathrm{C},{ }^{31)}$ it is expected that the reaction rate is controlled by the diffusion of sulfur in the glass. Since it has been reported that the diffusion coefficient of sulfur in glasses primarily depends on the viscosity of glasses, ${ }^{32)}$ the diffusion coefficient $D$ at $\eta=10^{4.5} \mathrm{Pas}\left(850^{\circ} \mathrm{C}\right)$ was estimated to be $3 \times 10^{-14}$ $\mathrm{m}^{2} \mathrm{~s}^{-1}$. The approximate diffusion length of sulfur $\left[(D t)^{1 / 2}\right]$ was $7.5 \mu \mathrm{m}$, which was one order magnitude smaller than the maximum size of the glass particles. The formation of bubbles, however, caused the thinning of glass layers surrounding bubbles, which reduced the diffusion path length required for sulfur. Therefore, it was important for the reaction between the chromophores and $\mathrm{ZnO}$ to form bubbles in the present study. In fact, the elimination of $\mathrm{CaCO}_{3}$ reduced the value of $h$ from 100 to $91^{\circ}$. It is known that the content of sulfur in ambers glasses is about 0.025 mass \%, which corresponds to $8 \times 10^{-6} \mathrm{~mol} \mathrm{~S} /$ $1 \mathrm{~g}$ glass. ${ }^{33), 34)}$ Since the content of sulfur in amber glasses was much lower than the addition amount of $\mathrm{ZnO}(2 \times$ $10^{-4} \mathrm{~mol} \mathrm{ZnO} / 1 \mathrm{~g}$ glass), it is deduced that the unreacted $\mathrm{ZnO}$ acts as light scatterers.

In the green glass, it was found that the green color was reduced by the addition of $\mathrm{SiC}$. Further addition of $\mathrm{SiC}$ to the $\mathrm{ZnO}$ added glass reduced $C^{*}$, as expected from the result of green glass, that is, the green color was reduced. Although the addition of $\mathrm{SiC}$ might have reduced $\mathrm{Fe}^{3+}$ to $\mathrm{Fe}^{2+}$ and increased green color, such an effect was not observed. The foam glass in which 2 mass $\% \mathrm{ZnO}$ and 0.1 mass $\% \mathrm{SiC}$ were contained looks pale lime green color, although the foam glass with no additives looks amber, as shown in Fig. 2.

\subsection{Mixed glass cullet}

As mentioned above, foam glasses made from amber glass cullet and green glass cullet were, both, decolorized by the addition of the same additives as decolorizing agents. $L^{*} C^{*} h$ values of foam glasses made from mixed glass cullet are depicted in Fig. 4. As expected from the results of green and amber glass cullets, the foam glass made from mixed glass was decolorized by the addition of $\mathrm{ZnO}$ and $\mathrm{SiC}$. Since the mixed glass included the colorless glass, the value of $L^{*}$ in the foam glass made from the mixed cullet was higher than those made from green and amber glass cullets.

\section{Summary}

We have succeeded in decolorizing foam glasses made from amber glass cullet, green glass cullet and mixed glass cullet. $\mathrm{ZnO}$ and $\mathrm{SiC}$ was effective as decolorizing agents for the foam glasses made from green glass cullet, amber glass cullet and mixed glass cullet. It is deduced that $\mathrm{ZnO}$ acts as mainly white scatterers and decomposers of chromophores in the foam glasses made from green glass cullet and amber glass cullet, respectively. $\mathrm{SiC}$ acted as absorbers of light in these foam glasses.

Acknowledgment The authors are grateful to $\mathrm{M}$. Murakami and S. Matsumoto for their assistance in the experiments.

\section{References}

1) Glass Bottle 3R Promotion Association, Data collection, http://www.glass-3r.jp/data/pdf/data_10.pdf, accessed 31/01/2018 [in Japanese].

2) R. R. Petersen, J. J. König and Y. Yue, J. Non-Cryst. Solids, 425, 74-82 (2015).

3) J. J. König, R. R. Petersen and Y. Yue, J. Non-Cryst. Solids, 447, 190-197 (2016).

4) G. Scarinci, G. Brusatin and E. Bernado, "Cellular Ceramics: Structure, Manufacturing, Properties and Applications", Ed. by M. Scheffler and P. Colombo, Wiley-VCH, Weinheim (2005) Chapter 2.7, pp. 158- 
176.

5) G. Brusatin, E. Bernardo and G. Scarinci, "Sustainable Waste Management and Recycling: Glass Waste", Ed. by M. C. Limbachiya and J. J. Roberts, Thomas Telford, London (2004) pp. 67-82.

6) J. García-Ten, A. Saburit, M. J. Orts, E. Bernardo and P. Colombo, Eur. J. Glass Sci. Technol. A, 52, 103-110 (2011).

7) M. B. Østergaard, R. R. Petersen, J. J. König, H. Johra and Y. Yue, J. Non-Cryst. Solids, 465, 59-64 (2017).

8) G. W. McLellan and E. B. Shand, "Glass Engineering Handbook", 3rd edition, McGraw-Hill, New York (1984) pp. 19-1-19-5.

9) J. König, R. R. Petersen and Y. Yue, Ceram. Int., 41, 9793-9800 (2015).

10) D. Kazmi, D. J. Williams and M. Serati, Int. J. Appl. Ceram. Technol., 00, 1-26 (2019).

11) S. Fotiadou, M. C. Limbachiya, A. N. Fried and J. J. Roberts, "Sustainable Waste Management and Recycling: Glass Waste", Ed. by M. L. Limbachiya and J. J. Roberts, Thomas Telford, London (2004) pp. 305-312.

12) L. Hu, F. Bu, F. Guo and Z. Zhang, Earth Enviro. Sci., 61, 012122 (2017).

13) Y. L. Wei, C. Y. Lin, K.-W. Ko and H. P. Wang, Mar. Pollut. Bull., 63, 135-140 (2011).

14) Glass Foam Business Cooperative Brochure of Organization Guide, http://www.supersol.jp/, da0c6e71b225968600f6c75dc0ea8a35.pdf, accessed $17 / 12 / 2019$ [in Japanese].

15) R. W. Douglas and M. S. Zaman, Phys. Chem. Glasses, 10, 125-132 (1969).

16) M. M. Morsi, S. I. El-sherbiny and K. M. Mohamed, Spectrochim. Acta A, 145, 376-383 (2015).

17) D. B. Rapp, M. A. Dorsey, M. M. Ashton-Patton and J. E. Shelby, Ceram. Trans., 141, 323-330 (2004).

18) T. Murata, M. Torisaka, H. Takebe and K. Morinaga, J. Non-Cryst. Solids, 220, 139-146 (1997).

19) A. Paul, Phys. Chem. Glasses, 15, 91-94 (1974).

20) C. Rodriguez-Navarro, E. Ruiz-Agudo, A. Luque, A. B. Rodriguez-Navarro and M. Ortega-Huertas, $\mathrm{Am}$.
Mineral., 94, 578-593 (2009).

21) R. F. Cooper and K. Chyung, J. Mater. Sci., 22, 31483160 (1987).

22) D. Das, J. Farjas and P. Roura, J. Am. Ceram. Soc., 87, 1301-1305 (2004).

23) H. Katsui, M. Oguma and T. Goto, J. Am. Ceram. Soc., 97, 1633-1637 (2014).

24) J. Roy, S. Chandra, S. Das and S. Maitra, Rev. Adv. Mater. Sci., 38, 29-39 (2014).

25) V. V. Afanas'ev, "Defects in $\mathrm{SiO}_{2}$ and Related Dielectrics: Science and Technology", Ed. by G. Pacchioni, L. Skuja and D. L. Griscom, Kluwer, Dordrecht (2000) pp. 581-597.

26) H. J. von Bardeleben, J. L. Cantin, M. Mynbaeva, S. E. Saddow, Y. Shishkin, R. P. Devaty and W. J. Choyke, "Silicon Nitride and Silicon Dioxide Thin Insulating Films VII", Proceedings Volume 2003-02, Ed. by R. E. Sah, K. B. Sundaram, M. J. Deen, W. D. Brown, D. Landheer and D. Misra, Electrochem. Soc., Pennington (2003) pp. 39-51.

27) H. Werheit and K. A. Schetz, J. Solid State Chem., 177, 580-585 (2004).

28) S. Logothetidis, Diamond Relat. Mater., 12, 141-150 (2003).

29) H. R. Phillip, J. Phys. Chem. Solids, 32, 1935-1945 (1971).

30) C. R. Bamford, "Colour Generation and Control in Glass", Glass Science and Technology 2, Elsevier, Amsterdam (1977) pp. 35-38.

31) M. Müller, C. Russel and O. Claußen, Glastech. Ber., 72, 362-366 (1999).

32) H. Behrens and J. Stelling, Rev. Mineral. Geochem., 73, 79-111 (2011).

33) Japan Glass Bottle Association http://glassbottle.org/ ecology/apply/, accessed 03/12/2019 [in Japanese].

34) R. Falcone, S. Ceola, A. Daneo and S. Maurina, Rev. Mineral. Geochem., 73, 113-141 (2011).

35) ICDD PDF-2 card No. 00-023-671.

36) ICDD PDF-2 card No. 00-039-1425. 